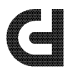 \\ COUNTERFUTURES \\ Left thought \& practice Aotearoa
}

\section{THREE}




\title{
Imagining an Aotearoa/New Zealand without Prisons
}

\author{
John W. Buttle
}

T IS HARD to remember a time when New Zealand has not been draconian in its attitudes towards punishment. Indeed, Tracey Macintosh observes that 'New Zealand society does not just have a tolerance for a high incarceration rate but an enthusiasm for it'. ${ }^{1}$ A national desire seemingly exists for a high level of incarceration whose effect, at the very least, is a systemic and needless waste of human potential. This desire sees a rising number of prisoners locked within a dehumanising and persistently expensive prison system. An effective response to this problem requires that the prevailing 'populist' understanding of punishment be abandoned. Ultimately, it will require imagining a society that is without prisons. Prior to that stage being

1 Tracey McIntosh, 'Prisoners, human rights, legislative measures and over-representation', Prison Forum, Looking into Prisons: Exploring 21st Century Principles and Practices, unpublished address, The Inaugural Bishop Selwyn Forum, Holy Trinity Cathedral Auckland, 17 October 2015, p 1. 
reached, however, an interim strategy of 'decarceration' is needed, one which reduces the levels of imprisonment such that the abolition of prisons becomes feasible. This involves the reform of elements within New Zealand's criminal justice system that proceed incarceration: the police, the courts, and sentencing in particular. Reforming these elements requires a serious engagement with the well-documented racial bias that characterises the operation of those fields.

\section{Mass incarceration in New Zealand}

Mass incarceration refers to the increase in people being imprisoned over a considerable period of time. ${ }^{2}$ However, the implications of this term stretch beyond the number of those incarcerated. The term mass incarceration also encapsulates the ideological intention to fill prisons no matter what the human or financial cost to prisoners and their families. Mass incarceration is not just about prisons, but includes the whole criminal justice system and the web of laws, regulations, and policies that constrain those who have been convicted, in and out of prison. ${ }^{3}$

Media representations and political discourse, often supported by far Right groups such as the Sensible Sentencing Trust, advocate for harsher sentencing on the pretext that Aotearoa/New Zealand is soft on crime. They are incorrect. Statistics on incarceration suggest the opposite. While the exact position in the international league tables is dependent on which comparative ratings are used, Aotearoa/New Zealand is one of

2 Ta-Nehisi Coates, 'The black family in the age of mass incarceration', The Atlantic, 2015, pp. 11-20.

3 Michelle Alexander, The New Jim Crow: Mass Incarceration in the Age of Colorblindness, New York 2010. 
the highest incarcerators in the world. In 2011, a comparison of imprisonment rates in 34 OECD countries indicated that this society's incarceration rates were the seventh highest, at 199 per 100,000 of the population. ${ }^{4}$ By 2015 , we had moved to the eighth highest out of 36 countries. ${ }^{5}$ This ranking far outstrips those of European jurisdictions and Australia.

A yearly increase in the number of people incarcerated has seemingly become an expectation of those living in Aotearoa/ New Zealand. In 2013, the total prison population reached 8,223 inmates - a rise of $300 \%$ since $1985^{6}$ - and in 2016 , the prison population was resting at 9,525 inmates, with future projections indicting that it could reach 10,000 sometime between August 2016 and May 2017. ${ }^{7}$ Even with new prisons having just been built, this dramatic increase in muster numbers has strained New Zealand's prison system. Many inmates are now two to a cell, while prison gyms and container units are being used to house prisoners. The cost of keeping each individual prisoner is approximately $\$ 97,000$ annually. With eye-watering yearly spends of around $\$ 165,000,000$ for remand facilities on top of the $\$ 590,000,000$ spent on sentenced prisoners (as per 2012), ${ }^{8}$ the affordability of prisons is questionable, especially given that they divert funds from social services.

The increasing rate of imprisonment has a racialised dimension to it. Moana Jackson first formally highlighted the prob-

4 'Imprisonment rates for OECD countries May 2011, Prison Population per 100,000', accessed 20 September 2016, http://www.teara.govt.nz/en/graph/36752/ imprisonment-rates-for-oecd-countries-may-2011

5 Council of Economic Advisors, Economic Perspectives on Incarceration and the Criminal Justice System, United States of America, New York 2016.

6 JustSpeak, Unlocking Prisons: How We Can Improve New Zealand's Prison System. Wellington 2014, p. 7. Henceforward, UP

7 Department of Corrections, 'Short-term (one year) Prison Population Forecast', Wellington 2016, p. 1.

$8 \quad U P$, p. 7 and p. 73. 
lem of Māori over-representation in the criminal justice system back in $1988 .{ }^{9}$ While only making up $15 \%$ of the general population in 2016, Māori inmates accounted for 51\% of the prison muster. At this time, Pacific peoples made up $11.2 \%$ of the prison population. This left the overall number of people of colour incarcerated at $62.2 \%$; by contrast, European prisoners make up $32 \%$ of those incarcerated. ${ }^{10}$ Māori are four to five times more likely to be apprehended, arrested, prosecuted, and convicted than nonMāori, 7.5 times more likely to receive a custodial sentence, and 11 times more likely to be remanded in custody while awaiting trial. ${ }^{11}$

To understand how this bias has occurred, it is important to consider the historical and social context that has shaped the treatment of Māori and other ethnic minorities by the criminal justice system of Aotearoa/New Zealand. Māori have experienced a long history of social control and cultural marginalisation aimed at enforcing the colonial state's assimilation policies. ${ }^{12}$ In the state's pursuit of assimilation, Māori have often been formally depicted as hopelessly criminal. Between 1853 and 1919, the British colonial government criminalised Māori whenever they rebelled. In times when Māori were silent, they were less likely to be incarcerated; when voices were raised in resistance, or when political activity against assimilation was undertaken, prisons were filled with Māori. ${ }^{13}$ The state has a history of incar-

9 Jackson, 'Maori and the Criminal Justice System, A New Perspective, Wellington 1988.

10 New Zealand Department of Corrections, 'Prison Facts and Statistics' Wellington March 2016, p 3.

11 Bronwyn Morrison, Identifying and Responding to Bias in the Criminal Justice System: A review of International and New Zealand Research, Wellington 2009, p. 20; Robert Webb, 'Incarceration', in Tracey McIntosh \& Malcom Mulholland, eds., Maori and Social Issues, Wellington 2011, p. 251.

12 Robert Webb, 'Māori, Pacific peoples and the social construction of crime statistics', MAI Review, 3 2009, pp. 1-4.

13 Simone Bull, 'The land of murder, cannibalism, and all kinds of atrocious crimes? Maori and crime in New Zealand 1853-1919', British Journal of Criminology, 44 2004, pp. 496-519 
cerating those that pose a threat to its Euro-centric understanding of the world. ${ }^{14}$ Racism has thereby become deeply entrenched in the culture and structure of the criminal justice system. One form of structural racism is related to the adversarial values of the Westminster style of justice, as used in Aotearoa/New Zealand. The punitive Westminster approach is at odds with Māori and Pasifika notions of justice, which are focused on healing the harm that crime has done to society. The institutional racial bias of our criminal justice system results in the disproportionate imprisonment of Māori and Pasifika peoples. ${ }^{15}$ Ending this bias would significantly reduce the prison population.

When social services are in greater need of funding, and with the incarcerated population expanding as fast, if not faster, than the state's ability to build prisons, the fiscal logic of mass incarceration is questionable. Considering the financial and moral costs of prisons to New Zealand, one might assume general support exists for the continuance of the prison system, on the basis that imprisonment achieves its social goals. However, that is not the case.

\section{Prison does not work}

Numerous attempts have been made to solve 'the problem of crime'. These attempts are often proclaimed to be 'the latest approach' to incarceration, frequently in the form of penal policies transferred from other jurisdictions. Greg Newbold describes how

14 Derwin Smith, Criminal Injustice: Maori, Racism and Mass Incarceration, Aotearoa: International Socialist Organisation 2014, p. 20. See also Jackson, Maori and the Criminal Justice System.

15 Human Rights Commission, A Fair Go For All: Discussing Structural Discrimination in Public Services, Wellington 2012. 
these initiatives are accompanied by enthusiastic rhetoric that lasts only until those involved realise it does not work. ${ }^{16}$ At such points, the approach is watered down and eventually abandoned. Sometimes the old approach is given a new name, and is reapplied with similar rhetorical zeal, but again largely to no avail. ${ }^{17}$ As such it can be claimed that the 120 year-old prison system of Aotearoa/New Zealand has consistently failed to achieve its goals. ${ }^{18}$ This is not a new or isolated assertion. The persistence of systemic failure in (and of) the institution is a readily-accepted fact within the international research community,

.... especially given that as recently as the mid-1970s, the most wellrespected criminologists were predicting that the prison would soon fade away .... The growing consensus among experts was perhaps best reflected by the [American] National Advisory Commission on Criminal Justice Standards and Goals, which issued a recommendation in 1973 that 'no new institutions for adults should be built and existing institutions for juveniles should be closed.' This recommendation was based on their finding that 'the prison, reformatory and the jail have achieved only a shocking record of failure. There is overwhelming evidence that these institutions create crime rather than prevent it. ${ }^{, 19}$

It seems the only effect that Western prison systems have achieved is the consistent reminder that they do not work.

Proponents of incarceration often cite the following as the main reasons why they believe imprisonment works: it reduces crime (deterrence); it ensures the safety of the public (con-

16 Greg Newbold, The Problem of Prisons: Corrections Reform in New Zealand since 1840, Wellington 2007, p. 10. Henceforward TPP.

17 Ibid., p. 10.

18 Ibid., p. 10.

19 Alexander, The New Jim Crow, p. 5. 
tainment); and it reforms criminals into useful members of society (rehabilitation).

The objective of deterrence is to reduce the likelihood of offending in the future through the threat of punishment. This is based on the assumption that fear of being incarcerated will lead people to make rational decisions to not offend, which will then reduce the crime rate. ${ }^{20}$ Deterrence has been the main goal of formal systems of punishment since their inauguration. Westminster style criminal justice systems, for example, are influenced by the $18^{\text {th }}$ century philosopher Cesare Beccaria, for whom deterrence was the core justification for punishment. ${ }^{21}$ From Beccaria's perspective, punishment must be delivered promptly. Immediate punishment was considered more likely to deter crime than deferred punishment. Further, for Beccaria, the perpetrator must be certain that they will be punished, and there can be no doubt in their mind of the consequences. Beccaria was not particular about the level of punishment needed, suggesting that people's knowledge that punishment would follow was the key to deterring crime. ${ }^{22}$ A practical problem associated with this philosophy is that no criminal justice system is ever prompt or certain in its punishment. Everyone who is caught committing a crime has to first wait for their court appearance, and then their sentencing. At the beginning of 2014, for example, criminal cases in Aotearoa/New Zealand would take, on average, 99 days to be tried in district courts. ${ }^{23}$ Also, a large majority of offenders who

20 Malcolm Davies, Hazel Croall \& Jane Taylor, Criminal Justice: An introduction to the Criminal Justice System in England and Wales, London 1995, p. 215. Henceforward $C J$.

21 Cesare Beccaria, 'On Crimes and Punishment', in John Muncie, Eugene McLaughlin \& Mary Langans, eds., Criminological Perspectives: A Reader, London 2001, pp. 4-13.

22 Frank P. Williams III \& Marilyn D. McShane, Criminological Theory, New Jersey 1999, pp. 14-24.

23 Ministry of Justice, Annual Report 2014/2015, Wellington 2015. 
have been sentenced to imprisonment have reported that they did not believe they would be caught, nor were they aware of the possible punishments they could receive. ${ }^{24}$ From the standpoint of Beccaria's justification for punishment then, the threat of imprisonment would have little or no deterrent effect on crime in Aotearoa/New Zealand. The antecedents of promptness and certainty are not present and, in all probability, never will be.

The effectiveness of prisons is further thrown into doubt by an ambiguous relation between rates of imprisonment and crime. In this country, the crime rate has been steadily dropping since the mid-1990s, while the rate of incarceration has been increasing. By contrast, in the Republic of Ireland crime has increased alongside a rise in incarceration. Alternatively, in, Finland crime rates have risen while incarceration rates have declined. ${ }^{25}$ Even countries with similar crime rates exhibit quite different trends in incarceration. The crime rates in Canada and the United States, in this regard, have both been falling for the last 20 years, but America has an incarceration rate of 715 per 100,000, while Canada incarcerates at a much lower 111 per $100,000 .^{26}$ From this it can be deduced that no relationship exists between the level of crime in a given society and its incarceration rates. This indicates that prison is not a deterrent, despite conservative conviction in the rationale.

Another supposedly important goal of prison is incapacitation: the imposition of physical restrictions on those who have been deemed offenders. This mostly refers to the incarceration of citizens who are considered dangerous, so as to prevent them from reoffending. To this end, imprisonment is justified on the

24 JustSpeak, Unlocking Prisons, p. 18.

25 United Kingdom National Audit Office, Comparing international Criminal Justice Systems: Briefing for the House of Commons Justice Committee, London 2012.

26 Franklin E. Zimring, The Great American Crime Decline, Oxford 2006. 
grounds of public protection. ${ }^{27}$ From this perspective, incapacitation is temporarily effective: it is difficult to cause harm to other members of society from behind high walls. However, this is only ever a temporary fix-at some point in time, the person incarcerated must be allowed to rejoin society.

Incarceration is the state's way of administering pain to citizens that have transgressed the prevailing matrix of rules, ${ }^{28}$ and nearly always focuses on inflicting harm on marginalised sections of society. Incarceration removes freedom and rights to citizenship. Even more insidious, however, is the eroding of inmates' individual identities and connections to social networks. ${ }^{29}$ Prison deprives people of their abilities to own goods and purchase services; they are deprived of heterosexual relationships; autonomy is taken away by rules that force specific behaviors on the individual; and personal security is reduced by enforced proximity to large numbers of people who are also considered criminal. ${ }^{30}$

It is fair to say that anyone that goes into prison will emerge from the other side of that painful experience a different person; it will rarely be a change for the better. ${ }^{31}$ Therefore, the notion of incapacitation as a means of protection is short lived if people return to society traumatized and more dysfunctional than when they were incarcerated.

Rehabilitation appears to respond to the failings of incapacitation. It attempts to alter the future behaviour of inmates

27 CJ, pp. 212-13.

28 Nils Christie, Limits to Pain: The Role of Punishment in Penal Policy, Eugene 2007, p. 2.

29 Erving Goffman, Asylums; Essays on the Social Situation of Mental Patients and Other Inmates, London 1991, pp. 24-36.

30 Gresham M. Sykes, The Society of Captives: A Study of a Maximum Security Prison, Princeton 1971, pp. 65-79.

31 Christie, Limits to Pain, p. 2. 
so that when they leave prison they do not reoffend. ${ }^{32}$ However, the prison system of Aotearoa/New Zealand has tended to fail in its attempts to rehabilitate those incarcerated. This is reflected in our high rates of recidivism. During 2015, 57\% of prisoners released were convicted of at least one offence and returned to prison within a 24 month period, and between 2006 and 2015, the recidivism rates ranged from $62.2 \%$ to $55.4 \% .^{33}$ The government's attempts to reduce recidivism rates by $25 \%$ between 2011 and 2017 showed an initial decrease, but the rate is now rising again. ${ }^{34}$ When taking age into account, younger people are more likely to reoffend (71\% under the age of 20$)$ and, as people get older, they are less likely to reoffend (35\% over the age of 40 ). ${ }^{35}$ This means that every time someone is incarcerated for the first time there is a higher probability that they will be incarcerated again, especially if they are young. Taking this failure of rehabilitation into consideration, it is hardly surprising that the local prison system has been growing for decades, as those who are incarcerated are more likely to re-offend than be rehabilitated.

With seeming regularity, even the more promising of rehabilitative programmes—such as those using Māori cultural identity to impart a variety of social skills and aptitudes-are adopted only to be later abandoned. ${ }^{36}$ The theory behind the Māori-based programmes, is that the establishment or reaffirmation of cultural identity has a greater chance of reducing re-offending than culturally non-specific programmes. In their evaluation of such initiatives, however, Juan Tauri and Robert

32 CJ, pp. 213-14.

33 Annaliese Johnston, Beyond the Prison Gate: Reoffending and Reintegration in Aotearoa New Zealand, Wellington 2016, p. 3.

34 State Services Commission, 'Better public services, reducing crime', accessed 22 February 2017, http://www.ssc.govt.nz/bps-reducing-crime.

35 Arul Nadesu, 'Reconviction patterns of released prisoners: a 60-months follow-up analysis', Wellington 2009, pp. 6-7.

36 TPP, p. 12. 
Webb find no evidence to support the effectiveness of these programmes at preventing reoffending. ${ }^{37}$ Despite the Corrections Department's rhetoric, they note, the Māori cultural identity programmes do not resemble Māori culture. ${ }^{38}$ The policy includes only those Māori concepts and practices that are acceptable to the state, and are only used in confined areas of the criminal justice system, ${ }^{39}$ such as those where Māori cultural beliefs and practices can be merged with existing Anglicized ones. ${ }^{40}$

The failure to achieve any of these functional goals throws into doubt the possibility that the prison system could influence this society for the better. Indeed, the reverse seems to be the case. Prisons increase the likelihood of crime, while soaking up resources better spent on social programs. Prison fails to deter crime and to rehabilitate inmates, while causing them considerable trauma and increasing levels of danger. In light of these matters, the only sensible conclusion is that the incarceration of people needs be avoided, and that prison is not a viable response to crime.

\section{What is prison abolition?}

Prison is perceived by most as an inevitable and permanent social fixture, an unassailable fact of social life that is seemingly impossible to challenge. ${ }^{41}$ Consequently, the idea that prisons should be abolished is likely to be considered an esoteric or aca-

37 Juan Marcellus Tauri and Robert Webb, 'A critical appraisal of responses to Māori offending', The International Indigenous Policy Journal, 3/4 2012, pp. 1-16.

38 Riki Mihaere, A Kaupapa Maori Analysis of the Use of Maori Cultural Identity in the Prison System, unpublished PhD thesis, Wellington 2015, p 3.

39 Juan Marcellus Tauri, 'Indigenous Perspectives', in Reece Walters \& Trevor Bradley, eds., Introduction to Criminological Thought, Auckland 2011, pp. 187-210.

40 Tauri \& Webb, 'A critical appraisal of responses to Māori offending'.

41 Angela Y. Davis, Are Prisons Obsolete? New York 2003, p. 9. 
demic luxury: neither the public, politicians, policy makers, nor other stakeholders in the provision of imprisonment will likely support it. ${ }^{42}$ Locally, abolition has traditionally been passed over in favour of a reformism that deals with isolated problems within the penal system. The reformist response has a history of supporting stern punishment and the idea that prison 'works', while applying ineffective rehabilitation programs. ${ }^{43}$ In the context of the repeated failure to either humanize the process of incapacitation or to lower recidivism rates, the pursuit of reformism exhibits the kind of madness associated with the repetition of failed actions in anticipation of different results.

Against a background of penal populism, which tends to entail politicians and the media ignoring evidence in favour of pandering to the public's supposedly punitive beliefs, ${ }^{44}$ reasoned national conversations on the abolition of prisons seems impossible. However, the recent controversy over the private management of prisons in New Zealand has brought the problems of incarceration to the forefront of public consciousness. Initially, the discourse focused on the incompetent management and poor human rights record of the prison provider SERCO, but deliberations have since widened to consider the emergence of mass incarceration as the prevailing problem. Considerable press coverage has been given to campaigns around the phenomenon, and a number of advocacy groups have opened spaces for discussion (notably, but not exclusively, JustSpeak and No Pride in Prisons). Given that the focus of such groups is the reduction of the prison muster, abolitionism has become a topic of discussion within these forums and, on occasion, is the main focus. eds., Penal Theory and Practice: Tradition and Innovation in Criminal Justice, Manchester 1994, pp. 263-84.

43 TPP, p. 12.

44 John Pratt, Penal Populism: Key Ideas in Criminology. Abingdon 2007, pp. 8-9. 
Towards this end, No Pride in Prisons' Abolitionist Demands Toward the End of Prisons in Aotearoa, outlines a strong abolitionist manifesto. ${ }^{45}$

Notwithstanding the increasing coherence of the local abolitionist programme, the notion of prison abolition continues to imply an impending release of dangerous criminals onto an unsuspecting public. This is obviously not the case. First, the abolition of prisons can only be achieved over time because alternatives have to be established, which is a time and energy consuming endeavour. Second, the majority of people incarcerated are not dangerous. As an indication of this, in 2016 only 18.4\% of those incarcerated were maximum or high security prisoners. The rest were categorized as minimum (at $28 \%$ ), low (at $22.8 \%$ ), and low medium (at 29.3\%). ${ }^{46}$ This means that $80 \%$ of inmates are not considered to be particularly dangerous by Corrections and probably do not need to be kept in prison. Further, the small percentage of prisoners that are in maximum security institutions may not be as dangerous as their classification indicates, even though they have committed serious offences. ${ }^{47}$

Removing prisons and the social harm they cause from the equation must involve measures to reduce the prison population. Therefore, the starting point of the abolitionist project should involve decarceration, which is defined here as getting people out of prison through such mechanisms as amnesty and of ensuring that people do not go to prison in the first place. Decarceration will not be accomplished without other factors also being

45 No Pride in Prisons, Abolitionist Demands: Towards the End of Prisons in Aotearoa, Auckland 2016; see also, this issue, 'No Pride in Prisons on Abolitionist Politics'.

46 Department of Corrections, 'Prison Facts and Statistics', March 2016, p. 4.

47 Joh Sorensen \& Jaya Davis 'Violent criminals locked up: examining the effect of incarceration on behavioural continuity', Journal of Criminal Justice, 29 2011, pp. 151-58. 
taken into consideration. ${ }^{48}$ A number of alternative social strategies and institutions need to be developed with the aim of replacing prisons, and the justice system must focus on reparation and reconciliation rather than retribution. ${ }^{49}$ This does not mean the proliferation of house arrest or electronic surveillance; rather, the transformation of the police into a caring and equitable social work agency, along with courtroom cultures that value the repair of social harm, and the encouragement of social responsibility for crimes. While most people who offend present no danger to the public, there is still a small percentage that do. Some of these people will have psychological problems and could be hospitalized, while others could be supervised in a non-prison environment.

Approached in this manner, prison abolition becomes as much about the transformation of social relations as it is about the eradication of crime. In the socio-cultural context of Aotearoa/ New Zealand, the abolition of prisons is about removing the racial bias against Māori and Pasifika peoples in the criminal justice system by reducing the number of people incarcerated, and providing alternatives to punishment that have the means to transform penal institutions into environments that no longer resemble prisons, but instead reflect the values of a caring society. The transformation must encourage social responsibility to participation in the healing of harm caused by any individual or group. Any policy adjustment, large or small, must have this sense of transformation as an orientating goal.

48 Mick Ryan \& Joe Sim, 'Campaigning For and Campaigning Against Prisons: Excavating and Reaffirming the Case for Prison Abolition', in Yvonne Jewkes, eds., Handbook on Prisons, Cullompton 2007, pp. 696-718. 


\section{The police}

Attempts to reduce the number of people in prison must start with a consideration of the role that the police play in mass incarceration. The police are the gate keepers who first expose people to the criminal justice system; this introductory stage is where racial bias first comes into play. In many ways, racism is firmly rooted in the structure of law enforcement as part of what is perceived as the police function, because all police organisations enforce the boundaries of social respectability. The respectable are the white working/middle class citizens who officers often treat with a certain amount of leniency by ignoring minor infractions. Alternatively, those groups that are outside, or on the border of respectable expectations-such as ethnic minorities, young men, the marginalised, and the disposed-become police property.$^{50} \mathrm{It}$ is the marginalised and disadvantaged who are most intensely policed, and throughout the world this section of the population has become defined more by race than by class. In Aotearoa/ New Zealand, despite the official references made to Te Tiritibased biculturalism, it is Māori and Pasifika peoples who fall outside Anglophone notions of respectability and who are at risk of becoming police property. They are the people who are stopped the most often and whose neighbourhoods are the focus of police attention.

Front line police officers have considerable discretion when it comes to making decisions about who they arrest and who they let off. The deep socio-cultural presuppositions of their shared belief systems influence their discretion when dealing with the public. ${ }^{51}$ As a consequence, racist stereotypes held by

50 P.A.J. Waddington, Policing Citizens: Authority and Rights, Abington 1999, p. 100.

51 Scott W. Phillips, 'Police discretion and boredom: what officers do when there is nothing to do, Journal of Contemporary Ethnography, 45/5 2016, pp. 580-601 
officers can influence where they focus their attention and who they deem to be on the border of respectability enough to arrest. Raumati Hook has demonstrated how stereotypes that infer criminality, such as the erroneous notion of 'the warrior gene', can lead to racial profiling of Māori by the police. ${ }^{52}$ Local research examining police/public interactions in terms of ethnicity is rare, but what has been done supports international research on racial profiling. Rates of contact between police and Māori youth under the age of 14 were found to be nearly three times higher than with non-Māori. ${ }^{53}$ Further, it has been found that Māori are more likely to be arrested for cannabis use than non-Māori. ${ }^{54}$ In this same vein, around $42 \%$ of all police apprehensions are found to be of Māori, ${ }^{55}$ and between 2010 and 2013 tasers were deployed against Māori and Pasifika peoples on 102 occasions per 10,000 as compared to a rate of 38 occasions per 10,000 for Pākehā. ${ }^{56}$ Subsequently, many Māori have a negative perception of the New Zealand Police-especially if they or their whanau have had previous contact. Māori commonly view the police as hostile to their culture and institutionally racist. ${ }^{57}$ A significant number of Māori are thereby understood to distrust the police on the basis that officers are assumed to have negative preconceptions about Māori.

52 G. Raumati Hook, “Warrior Genes": A response to peer commentaries', MAI Review, 2 2009, pp. 1-6.

53 D.M. Fergusson, L.J. Horwood \& M.T. Lynskey, 'Ethnicity and bias in police contact statistics', Australian and New Zealand Journal of Criminology, 26 1993), pp. 193-206.

54 D.M. Fergusson, N.R. Swain-Campbell \& L.J. Horwood, 'Arrests and convictions for cannabis related offences in a New Zealand birth cohort', Drug and Alcohol Dependence, 70 2003, pp. 53-63.

55 Department of Corrections, Over Representation of Maori in the Criminal Justice System: An Exploratory Report, Wellington 2007.

56 New Zealand Police, New Zealand Police Taser Reports-Key Findings, 22nd March 2010, to 30th June 2013. Wellington 2015.

57 New Zealand Police and Te Puna Kokiri, Challenging Perspectives: Police and Maori Attitudes Toward One Another, Wellington 2001. 
The New Zealand Police have previously attempted to address the racialisation of constables' perceptions and practices. In an attempt to foster more positive relations with Māori, a number of memoranda of understanding have been drawn up between the police and various iwi, and Māori responsiveness strategies have been devised. Perhaps the most solid expression of such initiatives involves the hiring of Māori officers and the introduction of Iwi Liaison Officers to act as bridges between Māori communities and the police. In his evaluation of such schemes, however, Tauri concludes that they are largely tokenistic. ${ }^{58} \mathrm{In}$ 2015/16, only 11. 3\% of officers identify as Māori and 5.5\% as Pasifika peoples, while Pākehā made up over $70 \%$ of sworn police. ${ }^{59}$ This small number of Māori officers supports Tauri's assertion that this is only a formalistic hiring process, and that, as a consequence, insufficient numbers of Māori and Pasifika officers have entered the police force for a change of culture to occur.

Historically, Māori have often joined the police as a means of facilitating the discourse of rangatiratanga. ${ }^{60}$ Then, like now, the inclusion of Māori officers in the police has had little influence over the organisation as a whole. A complex array of factors at the heart of policing are responsible for this lack of influence. These factors include the role the police play as enforcers of law within a colonised society, a socio-political context that engenders a racist disposition within police culture. ${ }^{61}$ The dimensions of this have been well documented. Much of the police's cultural values are transferred to new recruits when they first start

58 Tauri, 'Indigenous Perspectives'.

59 New Zealand Police, Annual Report 2015/2016, Wellington 2016.

60 Richard S. Hill, 'Maori Police Personnel and the Rangatiratanga Discourse', in Barry Godfrey \& Graeme Dunstall, eds., Crime and Empire 1840-1940: Criminal Justice in the Local and Global Context, Cullompton 2005, pp. 174-88.

61 Tauri, 'Indigenous Perspectives'. 
front line policing upon leaving the Police College. ${ }^{62}$ Within this setting, new constables who identify as Māori may find their beliefs subsumed by police culture. Even if that is not the case, then it is to easy for the police organisation to circumvent the cultural experience of Māori officers. Perhaps the most blatant example of this in recent years was the sidelining of Iwi Liaison Officers in the planning and execution of warrants for the 'Urewera raids' (in which Tuhoe people were illegally detained and unlawful road blocks set up). ${ }^{63}$ That the Iwi Liaison Officers where not consulted until after the raids suggests disrespect for their cultural expertise, and implies they were not trusted by other officers. All this points to a discriminatory and tokenistic approach on the part of police administration towards Māori society and culture.

Further, the presence of Māori police officers may not reduce racial profiling due to police officers' own perceptions of their role. Despite the fact that the police only spend a small amount of time catching criminals, a role in which police forces are not particularly effective, ${ }^{64}$ members still perceive crime fighting as the main reason for the institution's existence. Action-orientated violence and macho attitudes are also ingrained in officers through police culture. ${ }^{65}$ Māori officers are working in an environment where catching criminals is most valued. If they want to be considered as good officers, or seek promotion, then they must hold similar values. Therefore, Māori officers will be pressured to make arrests to validate their existence in the police. Consequently, like Pākehā officers, they may target those considered

62 Simon Holdaway, 'Constructing and sustaining race within the police workforce', British Journal of Sociology, 48 1997, pp. 18-34.

63 Te Ao Māori, 'Tuhoe want review of role of Māori Liaison Officers', Radio New Zealand, 23 May 2013, accessed 20 November 2016 http://www.radionz.co.nz/ news/te-manu-korihi/135818/tuhoe-want-review-of-role-of-maori-liaison-officers

64 Rod Morgan \& Tim Newburn, The Future of Policing, Oxford 1998.

65 Louise Westmarland, 'Police Cultures', in Tim Newburns, ed., Handbook of Policing, Collumpton 2008, pp. 253-311. 
the most stereotypically criminal (Māori and Pasifika) because it is these people that are perceived as police property. ${ }^{66}$

In 2011, the New Zealand Police revitalized their rhetoric of community policing by adopting a Prevention First strategy. ${ }^{67}$ This signalled the adaption of a problem-orientated and intelligence-led policing, as can be found in other countries. ${ }^{68}$ The rhetoric implies that prevention comes first, and that solutions for crime are employed that do not necessarily involve arrest. In apparent refutation of this policy, however, the high number of requests for police assistance from the organisation's three call centres suggests that the police are still mostly reactively answering public calls for assistance rather than prioritising prevention. ${ }^{69}$ Moreover, the prevention-first approach mixes community policing with a data-gathering approach, identifying hotspots and priority locations. This is presented officially as a data-driven process, but international evidence suggests this representation is inaccurate. The police tend to guide where they want to police and then find data to support their assumptions about where crime is happening. ${ }^{70}$ Police tend to still act upon their assumptions about the areas in which crime is most likely to occur. In short, our domestic force will most likely target the same Māori and Pasifika neighbourhoods as they always have because they will be looking for those people that are considered police prop-

66 Waddington, Policing Citizens p. 100.

67 New Zealand Police, Prevention First: National Operating Strategy 2011-2015, Wellington 2012.

68 Nick Tilley, 'Modern Approaches to Policing: Community, Problem-Orientated and Intelligence-Led', in Tim Newburns, ed., Handbook of Policing, Cullompton, pp. 376-403.

69 During the period of 2014/15, for example, the call centres took 1,840,078 requests for assistance. See New Zealand Police, Annual Report 2014/2015, Wellington 2015.

70 Nina Cope, 'Intelligence led policing or policing led intelligence, integrating volume crime analysis into policing', British Journal of Criminology, 442004 , pp.188-203. 
erty. The prevention-first strategy also indicates that the police will 'act with urgency against priority and prolific offenders', which is likely to result in some form of racial profiling.

In 2012, the police launched the Turning of the Tide strategy, in part, as a means of reducing the number of Māori prosecuted. Four years later, however, the strategy has failed to make a significant impact. ${ }^{72}$ The idea was to reduce the Māori arrest rate, which could best be achieved by setting up procedures that would reduce racial profiling, and by not over policing Māori and Pasifika neighbourhoods. However, neither of these elements appear to have been seriously considered. The police did publicly address the problem they have with racism, but it was more about deflecting blame away from the organisation than actually dealing with the problem: 'Police commissioner Mike Bush admitted the police force has been influenced by unconscious bias in their relations with Māori' ${ }^{73}$ By using the term 'unconscious bias', the police attempted to remove their agency from any claims that they are racist: they thereby sanitized their wrongdoing with denials of culpability. The inference is that they are being accidently racist. While there is some evidence to suggest that unconscious bias effects decision-making in situations that necessitate a quick response, the fact that the majority of policing does not involve making quick decisions suggests that its influence on officers is limited. ${ }^{74}$ Further, unconscious biases

71 New Zealand Police, Prevention First.

72 Nicholas Jones, 'Revealed: major police strategy to cut Maori crime statistics falling short', The New Zealand Herald, 23 August 2016, accessed 22 November 2016, http://www.nzherald.co.nz/nz/news/article.cfm?c_id=1\&objectid=11699010

73 Alison Harley, 'Commissioner: Police addressing bias in Maori relations', News Hub, 15 November 2015, accessed 22 November 2016, http://www.newshub.co.nz/ nznews/ commissioner-police-addressing-bias-in-maori-relations-2015112817.

74 Kathleen A. Tomlin \& Jill C. Bradley-Geist, 'Alignment between antecedents and interventions: the critical role of implicit bias', Industrial and Organisational Psychology-Perspectives on Science and Practice, 9/6 2016, pp. 583-90. 
emerge from conscious racial stereotypes. ${ }^{75}$ In order for a state of unconscious racial bias to become ingrained, conscious racism would need to be a constant and pervasive feature of officers' social and working culture. ${ }^{76}$

Conscious racism in the police force was demonstrated when the police attempted to discredit research on the experience that African peoples had in their interactions with the criminal justice system. ${ }^{77}$ This could have been an opportunity for the police to support the African community by stating that they will consider the findings and consult with the community; instead, they silenced the voices of the participants by attacking the credibility of the report and claiming it was un-scientific. ${ }^{78}$ This is relatively easy to do given that all research contains normative and political dimensions that go beyond the 'simply scientific'. Indeed, the New Zealand police have a history of trying to silence critical research by claiming it is un-scientific. ${ }^{79}$ In the case of the research just cited, the police's criticism has the form of a deliberate tactic exhibiting conscious racial bias.

Even with the appropriate social support and culturally appropriate community initiatives in place, the prison population will not go into decline if the police racially profile Māori and Pasifika youth. Unfortunately, the police seem unable to envisage a way to solve this problem. Despite the fact that the bulk of their role is similar to that of social work, they cling to the illu-

75 Ibid.

76 Robert Reiner, The Politics of the Police, Oxford 2000, pp. 98-100.

77 Camille Nakhid, et al, African Youth Experiences with the Police and the New Zealand Justice System, unpublished report, Auckland 2016.

78 Stuff, 'African leaders gather to discuss New Zealand Police racism claims', 5 March 2016, accessed 22 November 2016, http://www.stuff.co.nz/auckland/77582387/african-leaders-gather-to-discuss-police-racism-claims.

79 John W. Buttle \& Anjte Deckert, 'The Police Complaints Process', in Antje Deckert \& Rick Sarres, eds., The Australian and New Zealand Handbook of Criminology, Crime, and Justice, in press. 
sion promulgated by their work-culture that their main function is to solve crimes. ${ }^{80}$ For a process of decarceration to succeed, the 'tick box' approach to problem solving that characterises normal police work needs to be displaced by a service ethos that focuses on the provision of social care.

\section{Courts and sentencing}

The courts are a crucial way-station on the journey to prison. It is here that the conditions of the person's future will be decided, and it is by redirecting sentencing practices that much of the work towards decarceration might be undertaken. Again, it is Māori who are disproportionally disadvantaged in the sentencing process. Māori are 3.9 times more likely to be convicted of an offence than non-Māori, and nine times more Māori than nonMāori are remanded in custody to await trial, with seven times as many Māori given custodial sentences than non-Māori. ${ }^{81}$

A systematic examination of New Zealand's courtroom processes and sentencing bias is needed for the sites in which racism occurs to be identified. Even without this, however, a number of ways exist by which courtroom processes could be adjusted to enable decarceration. Over the years, the legal aid system of Aotearoa/New Zealand has slowly been eroded through a reduction of government funding, leaving those who cannot afford legal representation to defend themselves in court. ${ }^{82}$ Many

80 Morgan \& Newburn, The Future of Policing.

81 Khylee Quince, 'Maori and the Criminal Justice System in New Zealand', in Julia Tolmie \& Warren Brookbanks, eds., Criminal Justice in New Zealand, Wellington 2007, pp. 333-57.

82 Tess McClure, 'Legal aid funding limits creating justice gap', Stuff, 19 July 2014, accessed 10 March 2017, http://www.stuff.co.nz/national/crime/10285613/Legalaid-funding-limits-creating-justice-gap. 
of these instances may conceivably involve Māori and Pasifika people because of the disproportionate rate at which they occupy precarious socio-economic positions. People with no legal representation face the potential of being sentenced more harshly. ${ }^{83}$ Therefore, greater provision of legal aid for a wider range of people may reduce the number of those incarcerated.

A second move would involve a repeal of the Bail Amendment Act of 2013, as incarceration rates escalated after the introduction of that legislation. ${ }^{84}$ The Act reverses the burden of proof needed to receive bail. Previously, the prosecutor had to prove that the accused was not fit for bail, but now the defendant has to prove they are fit to be granted bail. Moreover, the Act removes the presumption of bail for 17 to 20 year olds who have served a previous sentence, increasing the number of people on remand and leading to a considerable increase in those incarcerated. ${ }^{85}$ Repealing this act would aid decarceration.

A third initiative would involve an assessment of prisoners serving sentences of two years or less. During 2013, threequarters of prisoners were serving sentences in that range. ${ }^{86}$ While the context of these prosecutions is unknown, it can be assumed that if a person has been sentenced for two years or less it is unlikely to be a serious offence. This raises the question whether these people should be in prison in the first place, and thus whether they could be immediately released. Adding to this argument is knowledge about age and reoffending rates. Desist-

83 Asher Flynn, Jacqueline Hodgson, Jude McCulloch \& Bronwyn Naylor, 'Legal aid and access to legal representation: redefining the right to a fair trial', Melbourne University Law Review, 40/1 2016, pp. 207-39

84 Robson Hanan Trust, Report to the Committee Against Torture on New Zealand's 6th Periodic Report, United Nations Convention Against Torture and Other Cruel, Inhuman or Degrading Treatment or Punishment, Wellington 2015,

85 No Pride in Prisons, Abolitionist Demands.

86 The Howard League, 'The state of the nation's prisons', 5 March 2015, accessed 25 November 2016, http://www.howardleague.org.nz/blog/the-state-of-the-nationsprisons 
ance studies indicate that prisoners are less likely to reoffend after the age of $35 .{ }^{87}$ Given that, in $2016,42 \%$ of those incarcerated ranged from 35 years to 84 years, ${ }^{88}$ there would be value in ensuring that inmates in this age range were considered for release. It is counter-productive to keep locked up those who are most likely to stop offending.

A fourth initiative involves the amendment, if not repeal, of the draconian sentencing laws which have become more numerous here in recent years. The most obvious case for repeal is the 'three strikes and you are out' law that was copied from the United States (regardless of evidence that it had failed to reduce or deter crime). ${ }^{89}$ While it is often the case that the 'three strikes' laws have had less of an impact on prison systems than anticipated, ${ }^{90}$ their potential to fill New Zealand's prisons by imposing needlessly harsh sentences remains a concern. The law dictates that a judge must impose the maximum penalty if a person has been convicted three times for violent or sexual offences. In one instance this has led to a prisoner having seven years added to his sentence for pinching a prison guard's bottom, a very severe penalty. ${ }^{91}$ Taking this into consideration, a case exists for the removal of mandatory sentencing and the return of sentencing discretion to judges, in the hope that this will reduce the number of people incarcerated.

87 Shadd Maruna, Making Good: How Ex-Convicts Reform and Rebuild Their Lives, Washington 2001.

88 Department of Corrections, 'Prison Facts and Statistics' p. 3.

89 Lisa Stolzenburg \& Stewart J.D. Alseeio, “Three strikes and you are out": the impact of California's new mandatory sentencing law on serious crime rates', Crime and Delinquency, 43/4 1997, pp. 457-69.

90 John Clark, James Austin \& Alan Henry, 'Are repeat offender laws having their anticipated effects?', Judicature, 81/4 1987, pp. 144-49.

91 Benedict Collins, 'Senior lawyers, politicians slam third-strike sentence', Radio New Zealand, 25 November 2016, accessed 26 November 2016, http://www.radionz.co.nz/news/political/318942/senior-lawyers,-politicians-slam-third-strikesentence. 
Another way of reducing prison numbers is to decriminalise victimless crimes. Victimless crimes may be irritating or generally annoying, but they are not injurious to others, and often only harm the perpetrator. Such offences include minor traffic infringements, possession and sale of illegal drugs, public intoxication, some forms of disorderly conduct, vagrancy, and truancy. ${ }^{92}$ The New Zealand government has already decriminalised prostitution, one of the main victimless crimes often listed, and homosexuality is legal. These examples indicate that the decriminalisation of victimless crimes does have precedence, even in this punitive culture.

Decarceration can only proceed as fast as social services in the community become available. ${ }^{93}$ To let people out of prison or to divert people away from prison when there are not adequate resources could be disastrous. Therefore, the reduction of prisoners must be achieved over time, with patience and provision.

\section{Therapeutic communities}

Needless to say, in an abolitionist world there is no room for the ethos of prison privitisation. Private prison companies use business models to fill prisons rather than to decarcerate, and they often use dangerousness as a tactic to lobby governments. ${ }^{94}$ However, even in the United States, which has a high number of violent crimes, many criminal justice stakeholders are aware that truly dangerous offenders are rare. When asked, prison wardens,

92 Burton Knopp \& Jon L. Regier, Instead of Prisons: Why are so Many People we Love Behind Bars, A Handbook for Abolitionists, New York 2005, p. 103.

93 Ibid., p 83.

94 Nils Christie, Crime Control as Industry: Towards Gulags, Western Style, Oxon 2000 . 
prison guards, judges, parole officers, and others involved in this sector express little faith in the system they run, and hold that anywhere between $70 \%$ to $90 \%$ of prisoners could be safely released. ${ }^{95}$ That said, it is appropriate that the public are protected from those few criminals who are truly dangerous, and measures must be taken not to free the wrong people. Conversely, it must be remembered that the effects of harmful prisons do more social damage that any mistake made by the wrong person being freed. While some prisoners deemed dangerous will suffer from psychiatric problems and be better suited to a secure hospital, others have been severely traumatized by their journey through the prison pipeline, where they have been in and out state institutions all their life. ${ }^{96}$ It seems naive to assume that a person who reacts badly to harsh state-sponsored environments will suddenly become a model citizen when they are put in a punitive prison environment. These are often the people who are last, or get passed over, for rehabilitation in the current system. The point is that prisons need to be replaced with environments that assist people beyond their points of trauma.

As prisons are closed down, part of the monitory savings could finance therapeutic communities. Generally, therapeutic communities are a miniature society consisting of staff and clients who support each other on whatever transitional purpose is being undertaken. ${ }^{97}$ They encourage environments that safeguard human dignity and minimize suffering, while simultaneously promoting social justice in ways that actively facilitate the

95 Knopp \& Regier, Instead of Prisons, pp. 81-2.

96 Erica R. Meiners \& Maisha T. Winn, 'Resisting the school to prison pipeline: the practice to build abolition democracies', Race, Ethnicity and Education, 13/3 2010, pp. 271-76. See also Tracey McIntosh and Stan Coster, 'Indigenous insider knowledge and prison identity', this issue.

97 Helana Gosling, An Invitation to Change? An Ethnographic Study of a Therapeutic Community for Substance Abuse, unpublished $\mathrm{PhD}$ thesis, Liverpool John Moore University, Liverpool 2015. 
reduction of social inequities. ${ }^{98}$ In short, these communities need to resemble something that is the total opposite of prisons. They need to appear, if not actually be, similar to any other place in New Zealand society where Māori, Pasifika, Asian, and Pākehā are all able to reside in communities with which they can identify. It is important that each person is treated as a citizen rather than a prisoner. This means voting rights need to be restored, as well as the right to work given for at least the minimum wage, the right to rent a home, the right to education, the right to high quality health care and dentistry, the right to purchase goods, and the right for family visits at any time. It is only in this type of supportive setting that rehabilitation stands a chance of influencing these citizens, but even when it fails these people should still be treated with the dignity of a citizen of Aotearoa/New Zealand.

\section{Beyond populist punishment}

The love affair with the draconian levels of punishment supported by penal populism has lead New Zealand in the wrong direction. Significant evidence indicates that this long experiment with incarceration fails. Prisons do not deter crime and fail to rehabilitate people. Incarceration harms inmates in ways that make them more likely to reoffend. To reframe the point: prison has not only failed, it has become part of the problem and especially so for Māori and Pasifika communities that have born the brunt of 'tough on crime' penal policies.

While not exhaustive, nor indeed the only way of concep-

98 David Scott \& Helana Gosling, 'Before prison, instead of prison, better than prison: therapeutic communities as an abolitionist real utopia?', International Journal for Crime, Justice and Social Democracy, 5/1 2016, pp. 52-66. 
tualizing the problem, this work draws attention to those parts of the criminal justice system that precede incarceration as a means by which movement toward the abolition of prisons might progress. This transitional step, of decarceration, places attention on the roles of the police, courts, and sentencing in the imprisonment process. Particular attention has been given here to the well-studied racial bias at work in those fields. Consideration has also been given to the notions of amnesty, of early release of prisoners, and to the amendment, if not repeal, of the punitive sentencing laws which arose in the period of penal populism.

In conjunction with this pursuit of decarceration, it is also important to understand the significance of adequate social support from culturally appropriate community initiatives as alternatives to imprisonment. Policing also becomes part of this picture through a heightened appreciation of the social work role police routinely play, over and above those associated with law enforcement.

It is only when the prisons have emptied out, when decarceration has occurred, and only those few inmates who pose a real threat to society are interred, that consideration can be given to the radical transformation of prisons. This transitional stage towards prison abolition needs to consider a number of cultural perspectives, from Māori and Pasifika peoples as well as Pākehā. The idea of the therapeutic community is well suited, in this respect, due to its caring and respectful ethos and the ease with which they can be adapted across cultures.

It will take considerable political will to reverse the disastrous direction the administration of criminal justice is currently heading. The constant tinkering with reforms, and the great claims about the potential of rehabilitation, has been proven ineffective, if not false. Endlessly repeating these approaches is a sure sign of political insanity. What is being proposed by abolitionists may seem radical to some, but it is, realistically, the only path left. A criminal justice system without the death 
penalty was unthinkable until it was abolished. Now, people can barely imagine what our country with the death penalty would be like. It is time to work towards a future where racially biased policing, courts, and prisons no longer play a part in the social landscape of Aotearoa/New Zealand. 
If you like what you have read, please subscribe or donate.

\author{
G \\ COUNTERF UTURES \\ Left thought \& practice Aotearoa \\ (C) Copyright Counterfutures 2017
}

